Vol. 12 (2003): 83-93.

\title{
Effect of anionic salts on some blood and urine minerals, acid-base balance and udder oedema of dry pregnant cows
}

Susanna Tauriainen

Department of Animal Science, PO Box 28, FIN-00014 University of Helsinki, Finland. Current address: Seinäjoki Polytechnic, FIN-60800 Ilmajoki, Finland, e-mail: susanna.tauriainen@seamk.fi

Satu Sankari, Satu Pyörälä

Department of Clinical Veterinary Sciences, PO Box 57, FIN-00014 University of Helsinki, Finland

Liisa Syrjälä-Qvist

Department of Animal Science, PO Box 28, FIN-00014 University of Helsinki, Finland

\begin{abstract}
The objective of this study was to determine the effect of an anionic diet on mineral metabolism, acid-base status and udder oedema of dairy cows fed grass silage based diets during the dry period. Eighteen pregnant, non-lactating Friesian cows were divided randomly into two groups according to their expected calving date. Dietary cation-anion balance (DCAB), calculated as mill equivalents $\left[\left(\mathrm{Na}^{+}+\mathrm{K}^{+}\right)-\left(\mathrm{Cl}^{-}+\mathrm{S}^{2-}\right)\right]$, for high DCAB (control) and low DCAB treatments were +254 and -41 $\mathrm{mEq} \mathrm{kg}{ }^{-1}$ dry matter $(\mathrm{DM})$, respectively. Anionic salts were ammonium chloride $\left(\mathrm{NH}_{4} \mathrm{Cl}\right)$, magnesium chloride $\left(\mathrm{MgCl}_{2}\right)$ and magnesium sulphate $\left(\mathrm{MgSO}_{4}\right)$. Cows received grass silage $(5.2 \mathrm{~kg} \mathrm{DM})$, hay $(0.9 \mathrm{~kg} \mathrm{DM})$ and a concentrate mixture $(2.7 \mathrm{~kg} \mathrm{DM})$ until calving. Blood and urine samples were collected 4,3, 2 and 1 week before the expected calving date, at calving, 1 day and 1 week after calving. Udder oedema was evaluated by a quantitative and a subjective method. Acidification resulted in a marked decrease in urinary $\mathrm{pH}$, increased urinary $\mathrm{Ca}$ excretion and a change in blood acidbase balance. Blood $\mathrm{Ca}^{2+}$ and plasma $\mathrm{Ca}^{\text {tot }}$ concentrations were more stable at parturition for the anionic group, although such differences were not statistically significant. Anionic salts (DCAB -41 $\mathrm{mEq} \mathrm{kg}^{-1} \mathrm{DM}$ ) did not cause udder oedema in experimental cows.
\end{abstract}

Key words: calcium, cows, ion balance, minerals, parturient paresis, udder oedema

\section{Introduction}

Several studies have demonstrated that feeding anionic salts during the prepartum period can result in a decline in the incidence of milk fever (Block 1984, Oetzel et al. 1988, Joyce et al. 1997). Anionic salts are defined as these containing greater amounts of negatively charged fixed anions $\mathrm{Cl}$ and $\mathrm{S}$ relative to positively 
charged cations $\mathrm{Na}$ and $\mathrm{K}$. These ions are important components for determining dietary cation-anion difference (DCAB), calculated as $\left[\left(\mathrm{Na}^{+}+\mathrm{K}^{+}\right)-\left(\mathrm{Cl}^{-}+\mathrm{S}^{2-}\right)\right] \mathrm{mEq} \mathrm{kg}{ }^{-1}$ dry matter (DM). In earlier studies we have shown that inclusion of anionic salts in a concentrate mixture used to supplement grass silage during the dry period has improved dairy cow calcium $(\mathrm{Ca})$ metabolism (Tauriainen et al. 1998abc). However, when potassium $(\mathrm{K})$ concentrations of grass silage exceed $30 \mathrm{~g} \mathrm{~kg}^{-1} \mathrm{DM}$, it becomes difficult to formulate a palatable diet to recommended DCAB levels. If DCAB remains positive, only negligible effects on Ca metabolism are observed (Tauriainen et al. 1998bc, 2001).

Feeding diets of low DCAB can have the disadvange of increasing the risk of udder oedema. Udder oedema has been reported postpartum when $\mathrm{CaCl}_{2}$ (Lema et al. 1992), $\mathrm{NaCl}$ or $\mathrm{KHCO}_{3}$ (Nestor et al. 1988) and $\mathrm{NaCl}$ or $\mathrm{KCl}$ (Randell et al. 1974) supplements have been fed during the dry period. In contrast, Tucker et al. (1992) reported that low DCAB diets led to a more rapid regression of udder oedema post partum. However, another study tentatively indicated that low DCAB diets were associated with severe udder oedema, although these findings were not fully documented (Tauriainen et al. 1998a).

The objective of this study was to evaluate the effect of anionic salts on mineral metabolism and possible occurrence of udder oedema associated with feeding a diet based on concentrate, grass silage and hay during grazing. Since quantitative measurement of udder oedema was not entirely satisfactory in an earlier study (Tauriainen et al. 2001), udder oedema was also evaluated using a visual method.

\section{Material and methods}

\section{Experimental design and treatments}

Eighteen multiparous Friesian cows (age $49 \pm$ 11 months) were selected from the research herd of the University of Helsinki. Cows weighed 660 $\pm 52 \mathrm{~kg}$ at the beginning of the trial, and were randomly allocated to one of two dietary treatments with 9 cows per diet. Cows were fed grass silage $\left(5.2 \mathrm{~kg} \mathrm{DM} \mathrm{d}^{-1}\right)$, hay $\left(0.9 \mathrm{~kg} \mathrm{DM} \mathrm{d}^{-1}\right)$ and an experimental concentrate mixture $(2.7 \mathrm{~kg}$ DM $\left.\mathrm{d}^{-1}\right)$. The experimental feeding period started 4 weeks prior to the expected calving date and ended at parturition. Immediately after calving the cows entered the routine nutrition and management program adopted at the research farm of the University of Helsinki.

Experimental diets were assigned as: Diet 1, representing high DCAB (control) and diet 2, representing low DCAB. Cows were divided into two blocks according to age (2nd parity and $>2$ nd parity). Within each block, cows were randomly assigned to one of two treatments in groups according to the expected calving date. Using the formula $\left(\mathrm{Na}^{+}+\mathrm{K}^{+}\right)-\left(\mathrm{Cl}^{-}+\mathrm{S}^{2-}\right) \mathrm{mEq} \mathrm{kg}{ }^{-1} \mathrm{DM}$, the high $\mathrm{DCAB}$ and low DCAB diets contained $+254 \mathrm{mEq} \mathrm{kg}^{-1} \mathrm{DM}$ and $-41 \mathrm{mEq} \mathrm{kg}{ }^{-1} \mathrm{DM}$, respectively. The low DCAB diet was formulated according to Tauriainen et al. (2001). Formulation of experimental diets and concentrate mixtures is shown in Table 1, while the chemical composition of experimental diets is presented in Table 2.

Cows were housed in a free stall barn. Cows were fed on an individual basis using an electronic transponder (Bio Control A/S, Norway) located on a collar placed around the cow's neck. Grass silage was offered twice daily (0600 and 1400) and hay and concentrates once daily (1430). In case of refused feed, refusals were weighed and the dry matter content was determined. Samples of grass silage, hay and concentrate collected each week were pooled; grass silage was combined into monthly samples and, hay into bales, and frozen. Grass silage DM was determined weekly by drying at $100^{\circ} \mathrm{C}$ for $24 \mathrm{~h}$. Cows were weighed and body condition was scored at the beginning of the experiment, two weeks later and after calving. Body condition was assessed on a scale from 1 to 5 where 1 represented extremely thin and 5 represented extremely obese animals (Windman et al. 1982). 
Vol. 12 (2003): 83-93.

Table 1. Formulation of experimental diets on dry matter basis.

\begin{tabular}{lcc}
\hline $\begin{array}{l}\text { Concentrate } \\
\text { Ingredient, } \%\end{array}$ & $\begin{array}{c}\text { High DCAB } \\
+254 \mathrm{mEq}^{-1} \mathrm{DM}\end{array}$ & $\begin{array}{c}\text { Low DCAB } \\
-41 \mathrm{mEq}^{-1} \mathrm{DM}\end{array}$ \\
\hline Oat & 32.01 & 30.81 \\
Wheat-protein & 22.30 & 19.66 \\
Oat bran & 10.52 & 10.80 \\
Barley & 19.89 & 16.34 \\
Wheat molasses & 8.12 & 8.33 \\
$\mathrm{CaCO}_{3}$ & & \\
$\mathrm{MgPO}_{4}$ & 1.08 & 1.34 \\
$\mathrm{NaCl}$ & 1.08 & 1.11 \\
$\mathrm{MgO}^{\mathrm{NH}_{4} \mathrm{Cl}}$ & 0.91 & - \\
$\mathrm{MgCl}_{2}$ & - & 3.99 \\
$\mathrm{MgSO}_{4}$ & - & 2.10 \\
Flavour premix & - & 1.43 \\
Plant oil $_{\text {Selenium mix }}$ & 2.71 & 2.78 \\
Vitamin mix & 0.68 & 0.58 \\
Trace element mix & 0.30 & 0.31 \\
Dietary inclusion, \% & 0.20 & 0.21 \\
$\quad$ Grass silage & 0.20 & 0.21 \\
$\quad$ Hay & 57.67 & 57.51 \\
$\quad$ Concentrate mixture & 32.54 & 32.56 \\
\hline
\end{tabular}

DCAB $=$ Dietary cation-anion balance

\section{Sample collection}

Blood from jugular vein and urine samples were collected before afternoon feeding, 4, 3, 2, and 1 week prepartum, on the day of calving, and 1 and 7 days postpartum. Two samples were collected into $5 \mathrm{ml}$ evacuated heparinized tubes (Venoject VT-050 SHL, Terumo Europe N. V., Leuven, Belgium). The first was centrifuged (1000 g for $8 \mathrm{~min}$ ) immediately after sampling and the resultant plasma was stored frozen $\left(-20^{\circ} \mathrm{C}\right)$ for $\mathrm{Na}^{+}, \mathrm{K}^{+}, \mathrm{Cl}^{-}$, total $\mathrm{Ca}, \mathrm{Mg}, \mathrm{P}$ and creatinine determinations. The second was stored frozen $\left(-20^{\circ} \mathrm{C}\right)$ for haemoglobin measurements. An additional sample was collected into a 2-ml syringe containing Ca-stabilised heparin (Pico 50, Radiometer Copenhagen) for measurements of acid-base status. Syringes were placed on ice after sampling. After an immediate determina-
Table 2. Dry matter intake (DMI), energy content, chemical composition on a dry matter (DM) basis and cationanion balance of experimental diets.

\begin{tabular}{|c|c|c|}
\hline & High DCAB & Low DCAB \\
\hline DMI kg d $^{-1}$ & 9.19 & 9.06 \\
\hline $\mathrm{ME}^{1)} \mathrm{MJ} \mathrm{kg}^{-1} \mathrm{DM}$ & 9.96 & 9.70 \\
\hline Crude protein, $\%$ & 13.29 & 13.69 \\
\hline Crude fiber, $\%$ & 23.27 & 23.00 \\
\hline $\mathrm{ADF}, \%$ & 31.54 & 22.91 \\
\hline NDF, $\%$ & 46.07 & 44.88 \\
\hline $\mathrm{Ca}, \%$ & 0.57 & 0.57 \\
\hline $\mathrm{P}, \%$ & 0.37 & 0.37 \\
\hline $\mathrm{Mg}, \%$ & 0.35 & 0.47 \\
\hline $\mathrm{K}, \%$ & 2.21 & 2.22 \\
\hline $\mathrm{Na}, \%$ & 0.20 & 0.20 \\
\hline $\mathrm{Cl}, \%$ & 0.91 & 1.75 \\
\hline $\mathrm{S}, \%$ & 0.23 & 0.32 \\
\hline $\mathrm{DCAB}^{2)} \mathrm{mEq} \mathrm{kg}{ }^{-1} \mathrm{DM}$ & +254 & -41 \\
\hline \multicolumn{3}{|c|}{ 1) Metabolizable energy calculated according to MAFF } \\
\hline \multicolumn{3}{|c|}{$\begin{array}{l}\text { 2) Dietary cation-anion balance calculated as milliequiva- } \\
\text { lents }\left(\mathrm{Na}^{+}+\mathrm{K}^{+}\right)-\left(\mathrm{Cl}^{-}+\mathrm{S}^{2-}\right) \text { per } \mathrm{kg} \text { DM. }\end{array}$} \\
\hline \multicolumn{3}{|c|}{ DCAB $=$ Dietary cation-anion balance } \\
\hline \multicolumn{3}{|c|}{$\mathrm{ADF}=$ Acid detergent fibre } \\
\hline \multicolumn{3}{|c|}{$\mathrm{NDF}=$ Neutral detergent fibre } \\
\hline
\end{tabular}

tion of blood gases in whole blood, the reminder of the sample was used for measurements of ionised $\mathrm{Ca}$ and $\mathrm{Mg}$ concentrations. Cow body temperature was measured before each blood sampling with a metal thermometer.

Urine samples were collected by manual stimulation of the vulva and were frozen prior to $\mathrm{pH}$, creatinine and $\mathrm{P}$ determinations. Five $\mathrm{ml}$ of urine were transferred into a tube containing $0.5 \mathrm{ml}$ of $12 \mathrm{~N} \mathrm{HCl}$ and frozen for subsequent of total $\mathrm{Ca}, \mathrm{Mg}, \mathrm{K}$ and $\mathrm{Na}$ determinations.

\section{Analyses}

Blood $\mathrm{pH}$, partial pressure of $\mathrm{CO}_{2}\left(\mathrm{pCO}_{2}\right)$ and acid-base excess were measured using a blood gas analyser (ABL 555 Acid-Base Laboratory, Radiometer A/S, Copenhagen, Denmark). Measurements of $\mathrm{pH}$ and $\mathrm{pCO}_{2}$ were corrected for 
Tauriainen, S. et al. Effect of anionic salts on dry cows

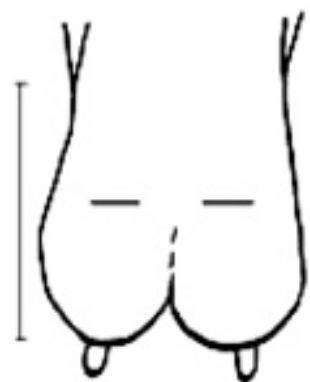

A

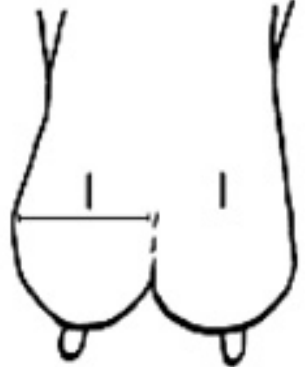

B

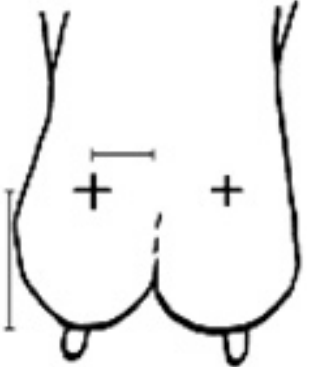

C
Fig. 1. The quantitative measurement method of udder oedema. A $=$ Drawing the halfpoint of the udder in the vertical level. B = Drawing the halfpoint of the udder in the horizontal level. $\mathrm{C}=\mathrm{The}$ proper measurement method of udder oedema: the measurement of vertical length and horizontal width. (Drawing: Susanna Tauriainen). measured body temperature for each cow according to the manufacturer instructions. Corrected $\mathrm{pH}$ and $\mathrm{pCO}_{2}$ values were subsequently used to calculate true bicarbonate $\left(\mathrm{aHCO}_{3}\right)$ and base excess $(\mathrm{BE})$ values. Plasma and urinary $\mathrm{Ca}$ and $\mathrm{Mg}$ concentrations were assessed by an atomic absorption spectrophotometer (Model 2380, Perkin Elmer Corp., Norwalk, Conn., USA), and creatinine concentrations were determined using an automated kinetic alkaline picrate method (Fabiny and Ertigshausen 1971). Inorganic phosphorus in plasma was determined based on the colorimetric method of Daly and Ertigshausen (1972). Concentrations of $\mathrm{Na}^{+}, \mathrm{K}^{+}$and $\mathrm{Cl}^{-}$in plasma (KONE Microlyte $3+2$, KONE Corp., Espoo, Finland) and ionised $\mathrm{Ca}$ and $\mathrm{Mg}$ in whole blood (Microlyte 6 Ion Selective Analyser, Konelab Corp., Espoo, Finland) were analysed using ion-specific electrodes.

Concentrations of $\mathrm{Na}$ and $\mathrm{K}$ in urine were determined using a flame photometer (Corning 480, Ciba Corning Diagnostics Limited, Halstead, UK). Urinary $\mathrm{pH}$ was measured with a pH meter (Radiometer Copenhagen, PHM 83 Autocal $\mathrm{pH}$ meter). Fractional excretion $\left(\mathrm{FE}_{\mathrm{x}}\right)$ of electrolytes $(\mathrm{x})$ was calculated as: $\mathrm{FE}_{\mathrm{x}}, \%=$ $\mathrm{x}_{\mathrm{u}} \times$ creatinine $_{\mathrm{p}} / \mathrm{x}_{\mathrm{p}} \times$ creatinine $_{\mathrm{u}} \times 100$; where $\mathrm{u}$ refers to urinary electrolyte concentration, and $\mathrm{p}$ to the corresponding concentration in plasma. The $\mathrm{Cl}$ content of the grass silage was determined according to AOAC (1984). Chemical composition of feeds was measured according to previously reported methods (Tauriainen et al. 1998a).
Udder oedema was evaluated by measuring the vertical height from the hind udder attachment to the root of the hind teat and the horizontal width from the outer edge of the udder to medial ligament and marking a cross at the intersection of these lines. Measurements were performed from the centre of the cross to the medial ligament and the root of rear teat of each side of the udder (Fig. 1). Evaluation was done two weeks from beginning of the experiment, at parturition, 1 and 2 weeks postpartum. The visual and manual evaluation of udder oedema was modified according to the 5-point system of Nestor et al. (1988). The scoring system was (Fig. 2): 1, no oedema; 2, slight oedema, defined as oedema in the base of the udder that had spread to one or more quarters, but not yet towards the navel; 3 , moderate oedema, defined the conditions for 2 , in addition to the appearance oedematous fluid in the navel and midline, but not yet spread upward in the rear of the udder; 4, marked oedema; oedema present in the entire udder; 5, marked and widespread, oedema being visible in the brisket moving upwards approaching the vulva.

\section{Statistical analysis}

Experimental data was analysed in two parts; prepartum from weeks 4 to 1 pre calving and peripartum from 1 week before the expected calving to 1 week after calving. Plasma and uri- 
Vol. 12 (2003): 83-93.
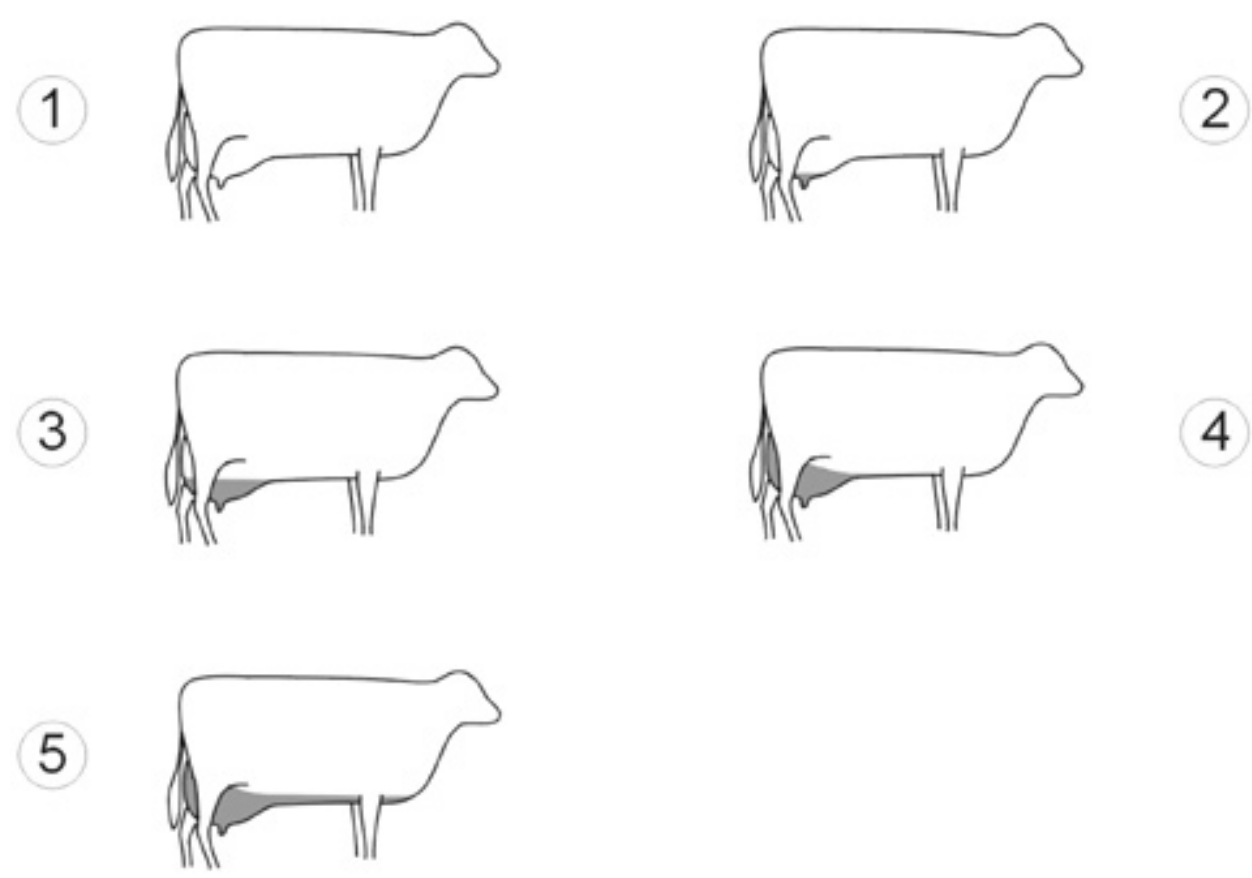

Fig. 2. Udder oedema scores (1 to 5). Hatched areas represent locations of oedema. (Drawing: Susanna Tauriainen).

nary data was analysed by repeated measures analysis of variance using the SAS (1985) general linear model procedure for a complete block design that included the effects of treatment, age and their interactions. Residuals of all data within dietary treatments were assessed for normality (Shapiro-Wilk test). A one-way analysis of variance of the two treatment groups was performed for data collected at 4 weeks precalving to assess initial differences between experimental groups. Due to significant differences between cows at the start of the trial in $\mathrm{Ca} /$ creatinine and $\mathrm{K} /$ creatinine, pre-treatment values were used as covariates. Data concerning udder oedema was analysed on a week by week basis using least squares analysis of variance, following the general linear models procedure. The statistical model included treatment, age and their interaction. For all statistical analysis, significance was declared at $\mathrm{P}<0.05$.

\section{Results}

Palatability of the experimental concentrate was good with no refusals. Mean body condition was 3.2 at the beginning of the trial and 3.1 at parturition. The daily portion of chloride- and sulphate salts in the concentrate mixture during the dry period did not significantly increase udder oedema during the period between 2 weeks before and 2 weeks post calving based on visual measurements of udder oedema. The cows entering 3 rd or greater loctation had more udder oedema 2 weeks postpartum (Fig. 3). For quantitative measurements, estimates of changes of horizontal width and vertical height were evaluated on a weekly basis to exclude a mutual correlation between age and udder size. Feeding had no effect on udder oedema (Fig. 4 and Table 3).

Two cows from the cationic group had signs 
Tauriainen, S. et al. Effect of anionic salts on dry cows

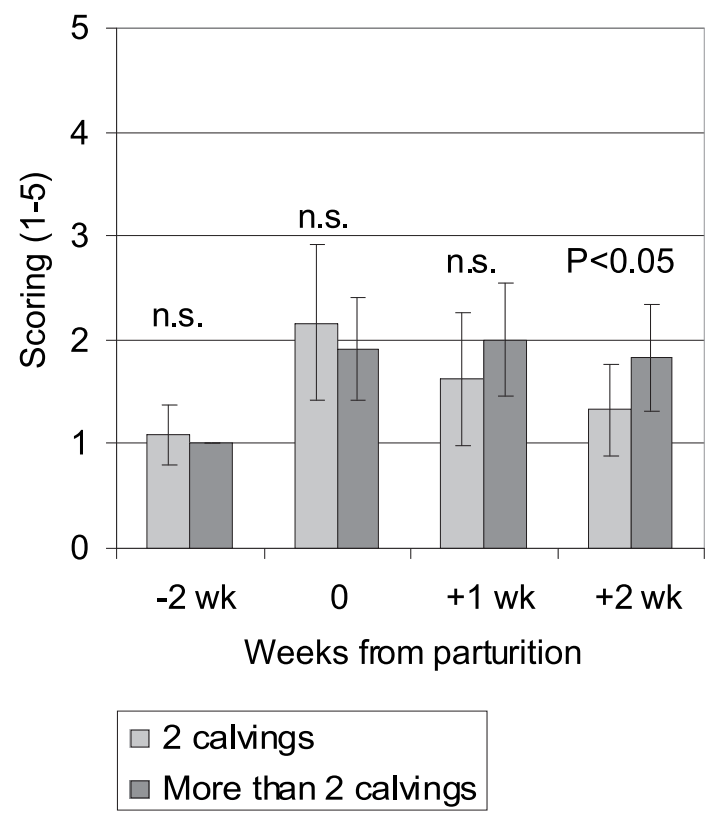

Fig. 3. Mean udder oedema of experimental cows with the 2nd calving and cows with more than two calving using the subjective evaluation method.

of clinical milk fever. The first case occurred at parturition and the cow received a calcium infu- sion after blood sampling $\left(\mathrm{Ca}^{2+}<0.88 \mathrm{mmol}\right.$ $\left.1^{-1}\right)$. The second case was noticed one week after parturition, and the cow was treated over two successive days following blood sampling $\left(\mathrm{Ca}^{2+}\right.$ $<0.81 \mathrm{mmol} \mathrm{l}^{-1}$ and $0.70 \mathrm{mmol} \mathrm{l}^{-1}$, respectively). Plasma $\mathrm{Cl}$ concentration was significantly higher for cows fed the low DCAB compared to the high DCAB diet cows (Table 4). A low DCAB had no effects on other blood mineral parameters. Older multiparous cows had significantly $(\mathrm{P}<0.05)$ higher blood $\mathrm{Mg}^{2+}$ concentration prepartum and significantly lower plasma $\mathrm{P}$ concentration peripartum than cows at their second calving.

A lowered DCAB tended to decrease blood $\mathrm{pH}(\mathrm{P}=0.057)$ and significantly decreased $(\mathrm{P}$ $<0.05)$ blood $\mathrm{HCO}_{3}$ and actual base excess (aBE) $(\mathrm{P}<0.05)$ prepartum (Table 5). Treatments and age had no effect on $\mathrm{pCO}_{2}$ during the trial.

Urinary Ca excretion was significantly higher $(\mathrm{P}<0.001)$ and urinary $\mathrm{pH}$ markedly lower $(\mathrm{P}<0.001)$ in cows fed the low DCAB diet (Table 6). Neither urinary excretion of $\mathrm{Mg}, \mathrm{K}$, and $\mathrm{Na}$, nor urine $\mathrm{FE} \%$ of $\mathrm{Mg}, \mathrm{K}, \mathrm{Na}$ or $\mathrm{P}$ were significantly influenced by experimental treatments.

Table 3. Mean vertical height and horizontal width of udder $(\mathrm{cm})$ fed diets with different dietary cation-anion balance (DCAB).

\begin{tabular}{|c|c|c|c|c|c|}
\hline & \multirow[b]{2}{*}{ Factor } & \multicolumn{4}{|c|}{ Time from parturition } \\
\hline & & $-2 w k$ & $0 \mathrm{wk}$ & $+1 \mathrm{wk}$ & $+2 \mathrm{wk}$ \\
\hline \multirow[t]{4}{*}{ Vertical height of udder, $\mathrm{cm}$} & High DCAB & 24.4 & 32.4 & 32.1 & 31.7 \\
\hline & Low DCAB & 27.7 & 32.6 & 30.5 & 30.4 \\
\hline & SEM & 1.24 & 0.92 & 1.12 & 0.97 \\
\hline & P-value & ns & ns & ns & ns \\
\hline \multirow[t]{4}{*}{ Horizontal width of udder, $\mathrm{cm}$} & High DCAB & 4.3 & 8.1 & 6.3 & 6.5 \\
\hline & Low DCAB & 4.6 & 7.9 & 6.5 & 5.8 \\
\hline & SEM & 0.30 & 0.63 & 0.55 & 0.59 \\
\hline & P-value & ns & ns & ns & ns \\
\hline
\end{tabular}

ns $=$ non-significant

$\mathrm{SEM}=$ standard error of means 
Vol. 12 (2003): 83-93.

Fig. 4. Mean udder oedema of experimental cows fed different cation-anion balance (DCAB) using the subjective evaluation method.

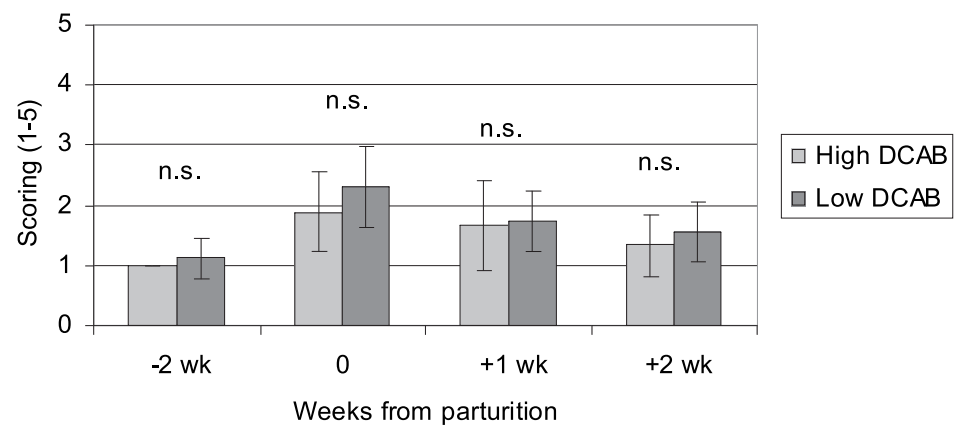

Table 4. Mean plasma mineral concentrations of dry cows fed diets with different dietary cation-anion balance (DCAB).

\begin{tabular}{|c|c|c|c|c|c|c|c|c|c|c|}
\hline & \multirow[b]{2}{*}{ Factor } & \multicolumn{7}{|c|}{ Time from parturition } & \multicolumn{2}{|c|}{ Significance } \\
\hline & & -4 wk & $-3 w k$ & $-2 w k$ & -1 wk & 0 & $+1 \mathrm{~d}$ & $+1 \mathrm{wk}$ & Prepartu & n Peripartum \\
\hline $\begin{array}{l}\text { Calcium }{ }^{2+} \\
\text { mmol l-1 }^{-1}\end{array}$ & $\begin{array}{l}\text { High DCAB } \\
\text { Low DCAB } \\
\text { SEM }\end{array}$ & $\begin{array}{l}1.31 \\
1.34 \\
0.018\end{array}$ & $\begin{array}{l}1.32 \\
1.32 \\
0.011\end{array}$ & $\begin{array}{l}1.32 \\
1.34 \\
0.014\end{array}$ & $\begin{array}{l}1.31 \\
1.32 \\
0.015\end{array}$ & $\begin{array}{l}1.11 \\
1.24 \\
0.035\end{array}$ & $\begin{array}{l}1.19 \\
1.18 \\
0.049\end{array}$ & $\begin{array}{l}1.21 \\
1.30 \\
0.054\end{array}$ & $\mathrm{~ns}$ & ns \\
\hline $\begin{array}{l}\text { Calcium }^{\text {tot }} \\
\text { mmol l-1 }^{-1}\end{array}$ & $\begin{array}{l}\text { High DCAB } \\
\text { Low DCAB } \\
\text { SEM }\end{array}$ & $\begin{array}{l}2.46 \\
2.51 \\
0.062\end{array}$ & $\begin{array}{l}2.47 \\
2.37 \\
0.023\end{array}$ & $\begin{array}{l}2.46 \\
2.43 \\
0.023\end{array}$ & $\begin{array}{l}2.47 \\
2.37 \\
0.034\end{array}$ & $\begin{array}{l}1.94 \\
2.29 \\
0.077\end{array}$ & $\begin{array}{l}2.16 \\
2.18 \\
0.086\end{array}$ & $\begin{array}{l}2.21 \\
2.39 \\
0.086\end{array}$ & $\mathrm{~ns}$ & ns \\
\hline $\begin{array}{l}\text { Magnesium } \\
\mathrm{mmol} \mathrm{l}^{\text {tot }}\end{array}$ & $\begin{array}{l}\text { High DCAB } \\
\text { Low DCAB } \\
\text { SEM }\end{array}$ & $\begin{array}{l}0.98 \\
0.94 \\
0.033\end{array}$ & $\begin{array}{l}0.97 \\
0.99 \\
0.023\end{array}$ & $\begin{array}{l}0.91 \\
1.03 \\
0.029\end{array}$ & $\begin{array}{l}0.94 \\
0.94 \\
0.031\end{array}$ & $\begin{array}{l}1.11 \\
1.07 \\
0.058\end{array}$ & $\begin{array}{l}1.00 \\
1.06 \\
0.043\end{array}$ & $\begin{array}{l}1.07 \\
0.96 \\
0.052\end{array}$ & ns & ns \\
\hline $\begin{array}{l}\text { Chloride } \\
\text { mmol l-1 }^{-1}\end{array}$ & $\begin{array}{l}\text { High DCAB } \\
\text { Low DCAB } \\
\text { SEM }\end{array}$ & $\begin{array}{c}101.5 \\
102.1 \\
0.60\end{array}$ & $\begin{array}{c}101.8 \\
103.3 \\
0.76\end{array}$ & $\begin{array}{c}101.9 \\
104.2 \\
0.72\end{array}$ & $\begin{array}{r}102.9 \\
104.5 \\
0.58\end{array}$ & $\begin{array}{c}105.4 \\
106.4 \\
0.89\end{array}$ & $\begin{array}{c}103.9 \\
103.7 \\
0.89\end{array}$ & $\begin{array}{c}100.3 \\
98.7 \\
0.72\end{array}$ & $*$ & ns \\
\hline
\end{tabular}

$\mathrm{P}<0.05 *, \mathrm{~ns}=$ non-significant

$\mathrm{SEM}=$ standard error of means

Table 5. Mean blood acid base balance of dry cows fed diets with different dietary cation-anion balance (DCAB).

\begin{tabular}{|c|c|c|c|c|c|c|c|c|c|c|}
\hline & \multirow[b]{2}{*}{ Factor } & \multicolumn{7}{|c|}{ Time from parturition } & \multicolumn{2}{|c|}{ Significance } \\
\hline & & $-4 \mathrm{wk}$ & $-3 \mathrm{wk}$ & $-2 \mathrm{wk}$ & $-1 \mathrm{wk}$ & 0 & $+1 \mathrm{~d}$ & $+1 \mathrm{wk}$ & Prepart & eripartum \\
\hline \multirow[t]{3}{*}{ Blood pH } & High DCAB & 7.38 & 7.39 & 7.39 & 7.39 & 7.37 & 7.38 & 7.38 & & \\
\hline & Low DCAB & 7.37 & 7.36 & 7.37 & 7.38 & 7.37 & 7.37 & 7.38 & & \\
\hline & SEM & 0.008 & 0.011 & 0.011 & 0.006 & 0.013 & 0.011 & 0.008 & $\mathrm{~ns}$ & $\mathrm{~ns}$ \\
\hline \multirow{3}{*}{$\begin{array}{l}\text { Blood } \mathrm{HCO}_{3} \\
\text { mmol 1-1 }\end{array}$} & High DCAB & 27.1 & 27.3 & 27.7 & 27.5 & 25.6 & 26.3 & 25.5 & & \\
\hline & Low DCAB & 26.9 & 25.3 & 24.9 & 25.3 & 25.6 & 27.5 & 28.2 & & \\
\hline & SEM & 0.62 & 0.65 & 0.74 & 0.77 & 1.10 & 1.15 & 0.73 & $*$ & $\mathrm{~ns}$ \\
\hline \multirow{3}{*}{$\begin{array}{l}\text { Blood aBE } \\
\mathrm{mmol} \mathrm{l}^{-1}\end{array}$} & High DCAB & 2.36 & 2.65 & 3.21 & 2.94 & 0.93 & 1.59 & 1.00 & & \\
\hline & Low DCAB & 2.05 & 0.42 & 0.42 & 1.10 & 1.05 & 2.61 & 3.58 & & \\
\hline & SEM & 0.587 & 0.594 & 0.769 & 0.732 & 1.132 & 1.110 & 0.729 & $*$ & ns \\
\hline
\end{tabular}

$\mathrm{P}<0.05 *$, ns $=$ non-significant

$\mathrm{SEM}=$ standard error of means

$\mathrm{aBE}=$ actual base excess. 
Tauriainen, S. et al. Effect of anionic salts on dry cows

Table 6. Mean urinary $\mathrm{pH}$ and calcium excretion of dry cows fed diets with different dietary cation-anion balance (DCAB).

\begin{tabular}{|c|c|c|c|c|c|c|c|c|c|c|}
\hline & \multirow[b]{2}{*}{ Factor } & \multicolumn{7}{|c|}{ Time from parturition } & \multicolumn{2}{|c|}{ Significance } \\
\hline & & -4 wk & -3 wk & $-2 \mathrm{wk}$ & $-1 \mathrm{wk}$ & 0 & $+1 \mathrm{~d}$ & $+1 \mathrm{wk}$ & Prepartu & Peripartum \\
\hline \multirow[t]{3}{*}{$\mathrm{pH}$ in urine } & High DCAB & 8.25 & 8.31 & 8.28 & 8.34 & 8.04 & 8.20 & 7.71 & & \\
\hline & Low DCAB & 8.24 & 6.43 & 7.22 & 7.39 & 6.82 & 8.01 & 8.05 & & \\
\hline & SEM & 0.178 & 0.237 & 0.205 & 0.213 & 0.202 & 0.117 & 0.200 & $* * *$ & $* *$ \\
\hline \multirow[t]{3}{*}{$\mathrm{Ca} /$ creat. $^{1)}$} & High DCAB & 0.20 & 0.40 & 0.36 & 0.18 & 0.01 & 0.06 & 0.42 & & \\
\hline & Low DCAB & 0.20 & 1.01 & 0.75 & 0.68 & 0.34 & 0.04 & 0.56 & & \\
\hline & SEM & 0.000 & 0.087 & 0.141 & 0.095 & 0.085 & 0.044 & 0.144 & $* * *$ & $*$ \\
\hline \multirow{3}{*}{$\mathrm{Ca} \mathrm{FE} \%^{2)}$} & High DCAB & 0.86 & 1.68 & 1.76 & 0.87 & 0.16 & 0.33 & 1.99 & & \\
\hline & Low DCAB & 0.86 & 4.37 & 3.23 & 3.36 & 1.75 & 0.16 & 2.34 & & \\
\hline & SEM & 0.000 & 0.402 & 0.631 & 0.502 & 0.476 & 0.204 & 0.591 & $* * *$ & \\
\hline
\end{tabular}

$\mathrm{P}<0.05 *, \mathrm{P}<0.01 * *, \mathrm{P}<0.001 * * *$

$\mathrm{SEM}=$ standard error of the means

1) $\mathrm{mmol} / \mathrm{mmol}$

2) fractional excretion

\section{Discussion}

The incidence of udder oedema was similar in the anionic group compared to control group. This indicated that daily supplements of anionic salts (3.2 Eq) during the dry period did not increase the risk of udder oedema peripartum. High intakes of sodium chloride (Randell et al. 1974, Jones et al. 1984, Nestor et al. 1988), potassium (Sanders and Sanders 1981) or a high ratio of potassium to calcium and magnesium have been shown to cause udder oedema peripartum (Sanders and Sanders 1982). In the current study sodium intake was $16 \mathrm{~g}$ per day, which approached published requirements of $12 \mathrm{~g}$ per day (Tuori et al. 2001). Furthermore, the $\mathrm{K} /(\mathrm{Ca}+\mathrm{Mg})$-ratio could be maintained below a recommended level of 2.2 (Kemp and t'Hart 1957), despite a relatively high dietary $\mathrm{K}$ concentration $(2.2 \%$ of DM). In an earlier study (Tauriainen et al. 2001) dietary $\mathrm{K}$ content of $3.4 \%$ of DM was found to have no influence on the incidence of udder oedema, when the dietary $\mathrm{K} /(\mathrm{Ca}+\mathrm{Mg})$-ratio was low (1.1). Intake of $\mathrm{Cl}$ should be prevented from exceeding $195 \mathrm{~g} \mathrm{~d}^{-1}$ to avoid the risk of udder oedema (Jones et al. 1984), as was the case in the present study $\left(153 \mathrm{~g} \mathrm{~d}^{-1}\right)$.
On the basis of the current study a visual method for the evaluation of udder oedema was more reliable than quantitative measurements, since the latter accounted for oedema spreading to the hind quarters, but not that towards the navel. In addition, the quantitative measurement of udder oedema is more time consuming. It appears that a subjective oedema rating system using a 10-point scale is a useful tool to accurately assess the severity of udder oedema in dairy cattle (Tucker et al. 1992).

The low DCAB diet resulted in higher ionised $\mathrm{Ca}$ at parturition relative to the high $\mathrm{DCAB}$, although these differences were not significantly different. This finding tends to suggest a beneficial effect of anionic salts on calcium metabolism. However, the proportion of total blood $\mathrm{Ca}$ in ionised form was significantly higher in the low DCAB group (55.5\%) prepartum compared to the high DCAB group (53.4\%). In healthy cows the concentration of ionised $\mathrm{Ca}$ is highly correlated with the concentration of the total $\mathrm{Ca}$, since concentrations of albumin, bicarbonate, phosphate, citrate and lactate are relatively constant (Lincoln and Lane 1990, Riond et al. 1995). However, the concentration of total $\mathrm{Ca}$ is not directly related in cows with abnormal Ca status (Kvart et al. 1982), such that the correlation be- 
Vol. 12 (2003): 83-93.

tween ionised and total $\mathrm{Ca}$ can change during milk fever (Carlström 1970). In the current study, increases in the proportion of ionised $\mathrm{Ca}$ in total blood $\mathrm{Ca}$ concentrations for the anionic group may be due to changes in blood acid-base balance. A decrease in blood $\mathrm{pH}$ shifts the equilibrium between ionised $\mathrm{Ca}$ and protein-bound $\mathrm{Ca}$ causing an increase in ionised $\mathrm{Ca}$ concentrations. Furthermore, protein binding of ionised $\mathrm{Ca}$ is dependent on hydrogen ion concentration (Thode et al. 1983, Szenci et al. 1988).

A marked decrease in urinary $\mathrm{pH}$ and increase in urinary $\mathrm{Ca}$ excretion was observed for cows fed anionic salts, indicating that acidification was successful. A decrease in blood $\mathrm{pH}, \mathrm{HCO}_{3}$ concentration and actual base excess (aBE) was observed in the anionic group one week after the start of the experiment. However, acidification of the diet was not excessive since cows rapidly compensated for the acid load and achieved acidbase balance at parturition. The results indicate that despite the high $\mathrm{K}$ content of grass silage ( $31 \mathrm{~g} \mathrm{~K} \mathrm{~kg}^{-1} \mathrm{DM}$ ) it was possible to influence $\mathrm{Ca}$ metabolism of the dry cow. In addition the palatability of the concentrate mixture was good, even though anionic salts were applied at maximum recommended levels $\left(3.2 \mathrm{Eq} \mathrm{d}^{-1}\right)$. In ruminants, the maximum tolerable level for dietary $S$ is $0.4 \%$ of DM, after which additional sulphur intake can decrease voluntary feed intake and induce toxicity. The maximum tolerance of dietary $\mathrm{Cl}$, when fed in the form of $\mathrm{NaCl}$, has been reported to be $9.0 \%$ for cattle and sheep (NRC 1980).

In an earlier study (Tauriainen et al. 1998c) low plasma Mg concentrations $\left(<0.85 \mathrm{mmol} \mathrm{l}^{-1}\right)$ at parturition were observed for some cows fed $17 \mathrm{~g} \mathrm{Mg}$ per day. In the current study none of the cows were hypomagnesaemic at parturition indicating that it was beneficial to provide additional $\mathrm{Mg}$ (37 $\mathrm{g} \mathrm{Mg} \mathrm{d}^{-1}$ ) above the current recommendations in Finland $\left(17 \mathrm{~g} \mathrm{Mg} \mathrm{d}^{-1}\right)$. Blood ionised $\mathrm{Mg}$ was significantly higher $(\mathrm{P}<0.05)$ prepartum and plasma inorganic $\mathrm{P}$ significantly $(\mathrm{P}<0.05)$ lower peripartum in multiparous cows than for cows at their second calving. Plasma $\mathrm{Mg}$ or inorganic $\mathrm{P}$ was not affected by DCAB, a finding in agreement with previous studies (Tucker et al. 1992, Joyce et al. 1997). Generally moderate hypophosphataemia and hypermagnesaemia are accompanied by a reduction in plasma $\mathrm{Ca}$ at parturition, suggesting that changes in $\mathrm{P}$ and $\mathrm{Mg}$ metabolism are related to hypocalsaemia rather than to the feeding of an acidic diet (Phillippo et al. 1994). However, the increase in plasma $\mathrm{Cl}$ concentration observed for the anionic group, can be attributed to supplements of chloride salt.

The results from the current study showed that $3.2 \mathrm{Eq}$ of chloride- and sulphate salts in daily portion of $-40 \mathrm{mEq} \mathrm{kg}{ }^{-1} \mathrm{DM}$ of DCAB could be used for the feeding of dry cows without increasing the risk of udder oedema. A clear increase in urinary $\mathrm{Ca}$ excretion and decrease in urinary $\mathrm{pH}$ were seen despite a high $\mathrm{K}$ content of grass silage ( $\left.31 \mathrm{~g} \mathrm{~K} \mathrm{~kg}^{-1} \mathrm{DM}\right)$. However, the amount of anionic salts currently offered represented the upper recommended limits, such that under practical conditions it is uncertain whether milk fever can be prevented in cows fed grass silage with a $\mathrm{K}$ content above $31 \mathrm{~g} \mathrm{~K} \mathrm{~kg}^{-1} \mathrm{DM}$.

Acknowledgements. The authors appreciate the technical assistance of Sakari Alasuutari, Riikka Rinne, Carolina Sjögård and Jari Hiljanen. The co-operation of Merja Holma is also gratefully acknowledged. This study was financially supported by Rehuraisio Ltd, the A. Kordelin foundation, the Oiva Kuusisto foundation and Seinäjoki Polytechnic.

\section{References}

Block, E. 1984. Manipulating dietary anions and cations for cows to reduce incidence of milk fever. Journal of Dairy Science 67: 2939-2948.
Carlström, G. 1970. Studies on parturient paresis in dairy cows. V. On the composition and calcium binding capacity of two bovine serum protein fractions, with 
Tauriainen, S. et al. Effect of anionic salts on dry cows

special regard to parturient paresis. Acta Veterinaria Scandinavica 11: 89-102.

Jones, T.O., Knight, R. \& Evans, R.K. 1984. Chronic udder oedema in milking cows and heifers. Veterinary Record 115: 218-219.

Joyce, P.W., Sanchez, W.K. \& Goff, J.P. 1997. Effect of anionic salts in prepartum diets based on alfalfa. Journal of Dairy Science 80: 2866-2875.

Kemp, A. \& t'Hart, M.L. 1957. Grass tetany in grazing milking cows. Netherlands Journal of Agricultural Science 5, 4: 4-16. (ref. Sanders, D.E. \& Sanders, J.A. 1982)

Kvart, C., Björsell, K.A. \& Larssen, L. 1982. Parturient paresis in the cow. Serum ionized calcium concentrations before and after treatment with different calcium solutions - classification of different degrees of hypo- and hypercalcemia. Acta Veterinaria Scandinavica 23: 184-196.

Lema, M., Tucker, W.B., Aslam, M., Shin, I.S., Le Ruyet, P. \& Adams, G.D. 1992. Influence of calcium chloride fed prepartum on severity of edema and lactational performance of dairy heifers. Journal of Dairy Science 75: 2388-2393.

Lincoln, S.D. \& Lane, V.M. 1990. Serum ionized calcium concentration in clinically normal dairy cattle, and changes associated with calcium abnormalities. Journal of the American Veterinary Medical Association 197, 11: 1471-1474.

Nestor, K.E., Jr., Hemken, R.W. \& Harmon, R.J. 1988. Influence of sodium chloride and potassium bicarbonate on udder edema and selected blood parameters. Journal of Dairy Science 71: 366-372.

NRC 1980. Mineral tolerance of domestic animals. National Research Council. Subcommittee on Mineral Toxicity in Animals. National Academy Press. Washishington, D.C. USA. 577 p.

Oetzel, G.R., Olson, J.D., Curtis, C.R. \& Fettman, M.J. 1988. Ammonium chloride and ammonium sulfate for prevention of parturient paresis in dairy cows. Journal of Dairy Science 71: 3302-3309.

Phillippo, M., Reid, G.W. \& Nevison, I.M. 1994. Parturient hypocalcaemia in dairy cows: effects of dietary acidity on plasma minerals and calciotrophic hormones. Research in Veterinary Science 56: 303-309.

Randell, W.E., Hemken, R.W., Bull, L.S., Douglas, L.W. 1974. Effect of dietary sodium and potassium on udder edema in Holstein heifers. Journal of Dairy Science 57: 472-475.

Riond, J.L., Kocabagli, N., Spichiger, U.E. \& Wanner, M. 1995. The concentration of ionized magnesium in serum during the periparturient period of non-paretic dairy cows. Veterinary Research Communications 19: 195-203.

Sanders, D.E. \& Sanders, J.A. 1981. Chronic udder edema in dairy cows. Journal of the American Veterinary Medical Association 178: 1273-1274.

Sanders, D.E. \& Sanders, J.A. 1982. Potassium and udder edema. Journal of the American Veterinary Medical Association 181: 324.

SAS 1985. SAS User's Guide, Statistics. 5th Edition SAS Institute Inc. Cary, NC.

Szenci, O., Felkai, F., Märcz, I. \& Takacs, E. 1988. Ionized calcium, total calcium and acid-base values of blood in healthy and acidotic dogs. Journal of Veterinary Medical A 35: 125-128.

Tauriainen, S., Sankari, S., Pyörälä, S. \& Syrjälä-Qvist, L. 1998a. Effect of anionic salts in concentrate mixture and calcium intake on some blood and urine minerals, acid-base balance and feed intake of dry pregnant cows on grass silage based feeding. Agricultural and Food Science in Finland 7: 523-533.

Tauriainen, S., Sankari, S., Pyörälä, S. \& Syrjälä-Qvist, L. 1998b. Effect of anionic salts in concentrate mixture and magnesium intake on some blood and urine minerals, acid-base balance and feed intake of dry pregnant cows on grass silage based feeding. Agricultural and Food Science in Finland 7: 535-543.

Tauriainen, S., Sankari, S. \& Syrjälä-Qvist, L. 1998c. Effect of anionic salts in concentrate mixture on some blood and urine minerals, acid-base balance and feed intake of dry pregnant cows on grass silage based feeding with high calcium intake. Agricultural and Food Science in Finland 7: 545-552.

Tauriainen, S., Sankari, S., Pyörälä, S. \& Syrjälä-Qvist, L. 2001. Effect of anionic salts and potassium intake on some blood and urine minerals and acid-base balance of dry pregnant cows on grass silage based feeding. Journal of Animal and Feed Science 10: 5771.

Thode, J., Fogh-Andersen, N., Wimberley, P.D., Moller Sorensen, A. \& Siggaard-Andersen, O. 1983. Relation between $\mathrm{pH}$ and ionized calcium in vitro and in vivo in man. Scandinavian Journal of Clinical and Laboratory Investigation 43: 79-80 (Suppl. 165).

Tucker, W.B., Hogue, J.F., Adams, G.H., Aslam, M., Shin, I.S. \& Morgan, G. 1992. Influence of dietary cationanion balance during the dry period on the occurrence of parturient paresis in cows fed excess calcium. Journal of Animal Science 70: 1238-1250.

Tuori, M., Kaustell, K., Valaja, J., Aimonen, E., Saarisalo, E. \& Huhtanen, P. 2000. Rehutaulukot ja ruokintasuositukset. Helsinki, 99 p. 
Vol. 12 (2003): 83-93.

\title{
SELOSTUS
}

\section{Anionisten suolojen vaikutus ummessa olevien lehmien veren ja virtsan kivennäisiin, happo-emästasapainoon sekä utarepöhöön}

\author{
Susanna Tauriainen, Satu Sankari, Satu Pyörälä ja Liisa Syrjälä-Qvist \\ Helsingin yliopisto
}

Kokeen tarkoituksena oli selvittää anionisten suolojen vaikutuksia ummessa olevien lehmien veren ja virtsan kivennäisaineenvaihduntaan, happo-emästasapainoon sekä erityisesti utarepöhöön.

Kationi-anioni -tasapaino laskettiin $\left[\left(\mathrm{Na}^{+}+\mathrm{K}^{+}\right)\right.$ $\left.-\left(\mathrm{Cl}^{-}+\mathrm{S}^{2-}\right)\right] \mathrm{mEq} / \mathrm{kg}$ kuiva-ainetta $(\mathrm{ka})$, ja se oli joko +254 tai $-41 \mathrm{mEq} / \mathrm{kg} \mathrm{ka}$. Lehmät saivat säilörehua $5,2 \mathrm{~kg} \mathrm{ka}$, heinää $0,9 \mathrm{~kg}$ ka ja täysrehua $2,7 \mathrm{~kg}$ ka neljä viikkoa ennen odotettua poikimista poikimispäivään saakka. Veri- ja virtsanäytteet otettiin 4, 3, 2 ja 1 viikkoa ennen odotettua poikimista sekä poikimis- päivänä, 1 vrk ja 1 viikko poikimisen jälkeen. Utarepöhö mitattiin ja arvioitiin silmämääräisesti.

Anioniset suolat alensivat virtsan $\mathrm{pH}$ :ta, lisäsivät kalsiumin erittymistä virtsaan ja muuttivat veren happo-emästasapainoa. Veren ionisoitunut kalsiumpitoisuus ja plasman kalsiumpitoisuus pysyivät anionisia suoloja saaneilla lehmillä poikimisen aikaan vakaampina kuin lehmillä, jotka eivät olleet saaneet anionisia suoloja. Anionisten suolojen syöttäminen $(-40 \mathrm{mEq} / \mathrm{kg} \mathrm{ka})$ ennen poikimista ei aiheuttanut lehmille utarepöhöä. 
